\title{
The Relationship Between Board Diversity and Corporate Financial Performance: Empirical Evidence from Five Selected Commercial Banks in Nigeria
}

\author{
Sixtus Cyprian Onyekwere ${ }^{1, ~ *}$, Samuel Wesiah ${ }^{2}$, Shukriyya Nuuman Danbatta ${ }^{3}$ \\ ${ }^{1}$ Department of Economics, Aduvie Pre University College Jahi, Abuja, Nigeria \\ ${ }^{2}$ Department of Tax and Regulatory Services, PwC, Lagos, Nigeria \\ ${ }^{3}$ Department of Accounting and Finance, University of Portsmouth, Portsmouth, UK
}

Email address:

sixtusonyekwere@gmail.com (S. C. Onyekwere)

${ }^{*}$ Corresponding author

To cite this article:

Sixtus Cyprian Onyekwere, Samuel Wesiah, Shukriyya Nuuman Danbatta. The Relationship Between Board Diversity and Corporate Financial Performance: Empirical Evidence from Five Selected Commercial Banks in Nigeria. International Journal of Finance and Banking Research. Vol. 5, No. 4, 2019, pp. 76-90. doi: 10.11648/j.ijfbr.20190504.13

Received: July 2, 2019; Accepted: August 4, 2019; Published: August 15, 2019

\begin{abstract}
The purpose of this research was to investigate the nature of the relationship between board diversity and financial performance of deposit money Banks quoted on the Nigerian stock exchange. Based on extensive review of the literature, three board diversity variables were identified namely gender (measured by the proportion of women in the boardroom), non-executive directors (measured by the proportion of non-executive directors that make up the boardroom) and board size. Financial performance was measured using Return on Assets (ROA) and Return on Equity (ROE). The Fixed effects Panel data regression model was used to test the nature of relationship between the board diversity variables and the financial performance variables, using secondary data from the Banks annual financial statements covering the period from 2006-2017. The result of the analysis showed that gender diversity has a statistically significant positive impact on banks financial performance. On the other hand, the study also indicated that non-executive directors and board size do not have a significant impact on banks performance. Based on the findings from this study, it was therefore recommended that quoted deposit money banks in Nigeria should raise female proportions in their boardroom so as to improve financial performance.
\end{abstract}

Keywords: Corporate Governance, Financial Performance, Board Diversity, Panel Data, Fixed Effects, Nigerian Banks

\section{Introduction}

The banking sector is central to the economic growth of any country's economy, since it influences the level of money stocks through the ability to create deposits and extend credit. The important role played by the financial systems in accelerating economic development is widely recognised and this can be traced back to the era of Goldsmith which shows that the financial sector of the economy would be a catalyst of economic growth if developed. The benefits derived from a healthy and developed financial system would be accruable to savings mobilization and efficient financial intermediation roles. Therefore, the failure of this sector affects the entire economy of any nation.

\subsection{Rationale of Research}

Understanding the relationship between Board characteristics and corporate performance has become extremely necessary given the wave of corporate frauds which has resulted to the failure of many corporate entities across the globe. Examples of such failed entities include Enron, WorldCom, Lehman Brothers, etc. In Nigeria, there were also recorded cases of corporate failures; examples of failed corporate entities in Nigeria that were attributed to poor corporate governance include, Oceanic bank plc, Wema bank plc, Fin bank, Spring bank, Afribank and the recent case of Skye Bank [2] (Abubakar, 2018). These are all linked to poor or ineffective board in the discharge of the oversight function over the firms they manage. As a result, there is need to 
examine the impact of board characteristics and financial performance of deposit money banks in Nigeria. Agency theory postulates that the separation of ownership and control in the corporate world gives room to conflict of interest with respect to managerial interests versus owner's interests [42] (Onakoya, Ofeegbu, \& Fasanya, 2009). Hence, devising an effective way of monitoring managerial decisions becomes essential for the board of directors in order to protect shareholders' interests [21].

Many studies have been undertaken within this topic area but no sufficient and conclusive study has been achieved so far regarding the relationship between board diversity and financial performance of banks in Nigeria. Hence, this study seeks to close the gap by adding additional insight on whether banks with diverse board structure in Nigeria perform better than their peers with less diverse boardroom structure. Specifically, this research will look at board diversity in terms of gender diversity, board size and non-executive directorship and examine whether they have significant impact on the performance of selected commercial banks listed on the Nigerian Stock Exchange.

\subsection{Statement of Problem}

As the "life blood" of the economy, the financial system plays a very crucial role as the "health" of the economy depends on it. Also, the importance of commercial banks to the functioning of the financial systems cannot be oversized especially in terms of mobilising savings for investment as well as in providing a payment platform that facilitates transactions and commercial activities in the economy. It then follows that if the banks "go down", the financial system also goes down and the economy will become crippled.

The issues of corporate governance (not only within the banking system but also to businesses in other sectors of the economy) have received great attention across the world as a result of many incidences of corporate failures [25] (Garba \& Abubakar, 2014). As the governing forum of corporate entities, the board of directors has come under severe critique as a result of the deterioration in shareholders wealth which is brought about by gross corporate mismanagement which has resulted to the failure of many well-established businesses in the past years across the globe. Such corporate failures have been attributed to lack of proper oversight functions by the board of directors who are saddled with the responsibility of providing the right direction, leadership and management over the entities in which they are entrusted to. The board of directors have also been criticized for not being able to properly monitor and manage the activities of top management staff who are responsible for the day-to-day activities and whose motives tend to be in conflict with the interest of owners as suggested by agency theory.

Many corporate governance reforms have pointed to the need to effect changes in to the boardroom in terms of composition, structure and ownership configuration [40] (Okon \& Afza, 2014). In order to implement the reform in the boardroom, it is important to understand what impact the proposed structural reform will have on corporate performance. Hence, this study is motivated by the desire to test what form of structural mechanism in the boardroom would prove most effective in enhancing corporate performance and thus acts as a panacea to the lingering issues of corporate failures. The authors believe that the findings from this piece of work would be useful to stakeholders in the Nigerian Stock Exchange as well as to the policy makers as it will provide evidence on the relationship between board structure and firm's financial performance.

\subsection{Research Objectives}

The study seeks to achieve following objectives:

Examine the relationship between board size and the financial performance of commercial banks in Nigeria.

Evaluate whether there is a relationship between the numbers of non-executive directors and financial performance of commercial banks in Nigeria.

Examine the extent to which gender diversity affects commercial banks performance.

\subsection{Research Questions (RQ)}

This research study seeks to find answers to the following specific questions:

Does board size have a significant impact on commercial banks financial performance?

To what extent does the number of non-executive directors affect commercial banks financial performance?

To what extent does the number of women in the boardroom impacts on commercial banks financial performance?

\subsection{Research Hypothesis}

In order to find answers to the above questions, the researcher has adopted the hypothesis below which are stated in null form.

Board size does not have a significant impact on banks financial performance.

The number of women in the boardroom does not have a significant impact on commercial banks financial performance.

The number of non-executive directors in the boardroom does not have a significant impact on commercial banks financial performance.

\section{Review of Related Literature}

\subsection{Conceptual Framework}

The study is guided by a conceptual framework in other to achieve the objective of the study which is aimed at showing the relationship between board diversity and financial performance of the selected banks. In the conceptual framework, definition and explanation of terms are provided. This is more of proving the reader with background knowledge into the concepts and terms being studied. 


\subsubsection{Board Diversity}

The study [49] Tirole (2006) pointed out that the enormous managerial discretion at the disposal of management board due to shareholders dispersion can result to abuse. To checkmate this abuse, good governance mechanisms is important. Furthermore, to increase corporate governance effectiveness, and to ensure that management abuse does not occurred then there is the need for board diversity [48] (Terjesen, Couto, \& Francisco, 2015). The variables chosen to proxy for board diversity include, board size, non-executive director, and women directors. The rationale for the choice of these variables are provided below, starting with women directors.

\section{i. Women Directors (Gender Diversity)}

Plethora of studies exists with argument for and against women exhibiting good characteristics that instils good corporate governance. The studies [10] Campbell \& Mingues-Vera (2008), and [22] Farrell \& Hersch (2005) found that female directors may have positive impact on firm performance and market value. The study [36] Nielsen \& Huse, (2010) averred that female directors reduce the level of conflict in corporate boards, and they use board development activities, such as work instructions, evaluations, and development programs to improve board effectiveness. Along the same line, [6] Azmi \& Barrett, (2013) argued that women are meticulous, risk averse, skilled in accounting and finance, and good decision-makers. This makes several researchers to have recently focused on the effects that female executives and directors may potentially have on the firm's financial performance and market value.

\section{ii. Independent/Non-Executive Directors}

The board comprises of executive and non-executive directors to protect the shareholders interest. The term independent directors often used interchangeably with outside directors and non-executive directors. Without independence non-executive directors will not be able to perform their role effectively and to provide unbiased judgments [34] (Naseem, Xiaoming, Riaz, \& Rehman, 2017). Non-executive directors are outside directors who are independent of the company. According to the study [39] Ogbechie and Koufopoulos, (2010), non-executive directors are referred to as independent directors because they have neither personal nor business relationships with the company. This means that non-executive is any director who is not a representative or member of the immediate family of a shareholder and who has no business relationship with the company but seats on the management board to help check the excesses that may arise from the executive directors.

\section{iii. Board Size}

Board size refers to the total number of members in the board of directors. Universal best board size has been identified by some studies. Factors such as organisational size, growth opportunities, legal requirements, demand conditions, board structure, financial strength, ownership structure, amongst others determine the size and composition of board
[18, 15] (Dorger, 2011; De Andres, Azofra and Lopez, 2005). However, researchers are unanimous in their view that factors such as costs implication, interest, experience, qualifications, financial strength, expected benefits should be the determining factors when considering board size [8, 23] (Boone, Field, Karpoff, \& Raheja, 2006; Ferreira, 2010).

The Nigerian banking codes as well as the Securities and Exchange Commission of Nigeria code state that the members of a board should not be less than five, and the scale and complexity of operation of the company should be the key determining factors. The Securities and Exchange Commission code further states that factors such as integrity, compatibility, independence, diversity and availability to attend meetings should be considered (SEC - N, 2011:11). Similarly, the Central Bank of Nigeria (CBN) banking governance code gives an indication of expected minimum number of board size.

\subsubsection{Financial Performance}

Financial performance of the selected banks is used as the dependent variable for this present research. Four proxies have been widely used for firms' performance in previous papers namely: Tobin's Q (a market valuation indicator), Returns On Assets (ROA) and Returns On Equity (ROE) (an accounting-based indicator) and Earnings Per Share (Naseem, Xiaoming, Riaz, \& Rehman, 2017). However, similar to the study [4] Ali \& Nasir (2015), this present research adopts only ROA and ROE as its proxies for financial performance. ROA is the ratio of net income to the book value of the firms' assets, and is commonly used in studies of board composition and firm performance [19] (Easterwood, Ince, \& Raheja, 2012), while ROE is the ratio of net income to shareholder equity.

\subsection{Theoretical Background}

This topic is built on the theory of corporate governance and firm performance. The study of corporate governance is complicated by the fact that the structure, composition, role, and impact of boards have been studied from a variety of theoretical perspectives. Contributions have been made by scholars from different disciplines on corporate governance. Thus, numerous theories have emerged such as the agency theory, stewardship theory, resource dependence theory, institutional theory, transaction cost theory, and stakeholder theory, amongst others. The common aim of all these theories of corporate governance has been to posit a link between various characteristics of the board and corporate performance [31] (Kiel \& Nicholson, 2003).

Among these theories, the agency theory according to the study [50] Ujinwa, Okoyeuzu, \& Nwokoby (2012) is quite dominant in the corporate governance literature. According to the theory, the separation between ownership and control requires an agency relationship, which is an incomplete contract between owners as principals and managers as agents [29, 30] (Jensen, 1993; Jensen \& Meckling, 1976). This theory according to the authors has stimulated several governance researches and the adoption of various corporate governance principles and codes in several countries. The underlying 
assumption of the theory is the importance of an independent board as a strategy for resolving this conflict of interest between principal and agents [50] (Ujinwa, Okoyeuzu, \& Nwokoby, 2012).

Therefore, according to this framework, a firm's CEO has incentives to influence the selection of a board that will enable him/her to maximize his/her personal benefits [50] (Ujinwa, Okoyeuzu, \& Nwokoby, 2012). In contrast, directors have incentives to maintain their own independence, preventing them from being complacent about the CEO. Consequently, from the agency theoretical perspective, independent directors will have lesser potential conflicts of interest and therefore are in a position to provide greater integrity and independent judgment [45] (Rosenstein and Wyatt 1997). Consequently, it is envisaged that independent directors will more likely represent shareholder interests and potentially improve corporate governance [3] (Adams \& Ferreira, 2009). Moreover, agency theory express that a greater proportion of independent directors will be more capable to monitor company because managers will have less opportunity to pursue self-interest [35] (Nicholson \& Kiel, 2007). Nevertheless, agency theory is criticized to be too Anglo-Saxon specific [43].

\subsubsection{Arguments for Positive Impact}

The study [16] Dehaene, Naccache, Cohen, Bihan and Margin (2001), found a significant positive association between the number of external directors and return on equity. The results of this study show evidence backed up by the argument that non-executive directors provide superior benefits to the company due to their independence from the management of the organization. This single act of independence attracts investors in investing more into the organizations as it helps them in making better investment decisions.

The paper [52] Anderson, Reeb, Upadhyay, and Zhao (2011) study the potential cost and benefit of building board diversity. They use Tobin's Q as a proxy of financial performance and measure board diversity with six dimensions included gender and nationality. The empirical result indicates that a heterogeneous pool of directors positively affects firm performance. This result implies that board diversity improves board efficiency and is considered by investors as protecting or benefiting their interests. Besides, board diversity is also related to operational complexity.

The study [42] Oxelheim and Randøy (2003) analysed the effect of foreign board members on corporate performance which is measured by Tobin's Q. Their samples are Norwegian and Swedish firms and their result shows a significant positive impact. They note that recruitment of an outsider Anglo-American director indicates a significantly higher firm value than a Norwegian nor a Swedish director and this can be seen as an alternative to reduce cost of capital.

Similarly, the study [48] Terjesen, Couto, \& Francisco, (2015) adopts a multi-country study sought to establish the link between the presence of the independent and women directors on firm performance. By using data from 3,876 public firms in 47 countries and controlling for a wide set of corporate governance mechanisms, they establish that firms with more female directors have higher firm performance as measured by Tobin's $Q$ and accounting (return on assets) measures. Using data from about 679 organisations listed in the 1,000 data base, the study [32] Krishnan and Park (2005) investigated the relationship between female directors and the return on total assets and found positive correlation between having women on management board and financial performance. Consistent with this argument the study [11] Carter, Simkins and Simpson (2003) examined the nature of correlation between Tobin's Q and women inclusion in board management of the Fortune 1,000 companies and also found statistically significant positive correlation. Thus, the implication of these findings is that women inclusion on management board improves performance of the organisation as they tend to bring in various innovative and lofty ideas or opinions that will result to greater range of perspectives, which they eventually reach good decisions and better performance. The study [9] Burgess and Tharenou, (2002) noted that the good decisions do metamorphose into higher business value and financial performance of organizations. Furthermore, the study [4] Ali \& Nasir (2015) used panel data regression for Pakistan manufacturing firms and finds that all the board diversity variables (board size, independent $\mathrm{CEO} /$ Chairman and duality) have significant positive impact on financial performance.

\subsubsection{Arguments for Negative Impact}

The study [52] Anderson, Reeb, Upadhyay, and Zhao (2011) also extends to the discovery of a negative relationship. The authors maintain that when a company faces complex operations, a diverse board increases performance but exhibits a negative impact on performance in a company with less complex operating environments. Consistent with this is the work of Adams and Ferreira (2009) also found that the average effect of women directors on firm performance is negative.

\subsubsection{Arguments for No Impact}

The study [53] Alm and Winberg (2016) researched on the effect of gender diversity on firm performance. The study was based on panel data for 255 companies over a period of six years from Germany using pair-wise correlation matrix to test for multicollinearity. They found that there is no statistically significant relationship between ROA nor Tobi's Q and the female gender. Furthermore, the variable shows that there is no clear link between gender diversity-performance relationships.

Similarly, the study [51] Zainali, Zulkifi, \& Saler, (2013) investigated the influence of corporate board diversity in Malaysia with bias to gender and nationality of board members. The authors made use of Mann-Whitney $U$ test to identify several characteristics that differentiate between firms with women and foreign directors. Finding from their study shows just a little change in the presence of women directors and foreign directors. Thus, suggesting that having women in the board does not necessarily improve firm performance. In consistent with this, the study [44] Rose (2007), using data from Denmark reports that there is no significant relationship between firm performance and female on board representation. 
Consequently, the study [1] Abu, Okpeh, \& Okpe (2016) sampled 15 banks in Nigeria. Using multi-variate GLM regression method, they argue that women directors, boad size and and non-executive directors have no impact on ROA and ROE. The paper only reported impact for foreign directors.

\subsection{Conclusion}

From the review, while majority have found evidence that board diversity positively impacts financial performance, others argue that there is no impact. Also, there are those who argue that in fact, board diversity has negative impact on financial performance. Thus, there exists serious contention among researchers on this topic, making the research results inconclusive. This present research is therefore necessary to bring about a strong conclusion on the topic. The major gap in literature is the limited amount of papers investigating the topic for Nigeria, especially in the banking sector. Again, some of these studies are longitudinal studies and others are multi-sectoral studies conducted for different countries other than Nigeria. Thus, the governance structure in these countries differs from that of Nigeria. Furthermore, interest of researchers has been channelled towards developed countries such as, Germany, the U.K., and Norway amongst others. This study just like [1] Abu, Okpeh, \& Okpe, (2016) intends to examine only the banking sector in Nigeria by looking at the relationship between board diversity (board size, non-executive directors, and gender diversity) and financial performance for the selected banks. The study is also similar with the works of [24] Fidanoski et al (2014), [4] Ali \& Nasir (2015) and [48] Terjesen et al. (2013), as it examines similar variables. However, it differs in terms of country of investigation. Consequently, the study adopts the Panel multiple linear regression models as used by [24] Fidanoski et al (2014), [4] Ali \& Nasir (2015), [1] Abu, Okpeh, \& Okpe, (2016), and [48] Terjesen et al (2013). The research questions and hypotheses developed from this literature review have been placed in section 1 to inform the reader of the direction of the research. In consistence with [4] Ali \& Nasir (2015), and [1] Abu, Okpeh, \& Okpe, (2016) the data for this research includes many banks in Nigeria (as pointed out in section 1) which implies that it has both cross-section as well as time series dimensions. Thus, panel data estimation technique is most appropriate to employ for this analysis in agreement with [34] Naseem, Xiaoming, Riaz, \& Rehman (2017) and [4] Ali \& Nasir (2015). Further discussion on methodology is provided in section 3 .

\section{Methodology}

This section discusses how the data will be gotten and the methods of transforming the data into information needed to answer the research questions.

\subsection{Data Description/Source}

The researchers sampled five commercial banks quoted on the Nigerian Stock Exchange namely, Access Bank, Zenith
Bank, UBA, First Bank and GT Bank. The choice of these five banks is to ensure the researchers gather as much data as possible within the time frame available for the research.

The data was obtained by downloading the annual reports of the individual banks chosen for the research. This is the same approach [4] Ali \& Nasir (2015) and [1] Abu, Okpeh, \& Okpe (2016) used in obtainning the data for their research although for different set of banks. This present research is a little different from the mentioned papers as it makes use of more recent data which captures the duration of the recession in Nigeria between 2015-2017, which [4] Ali \& Nasir (2015) and [1] Abu, Okpeh, \& Okpe (2016) did not capture in their data.

To make sure the data is representative enough; the chosen banks come from both the earliest to more recently established banks. Zenith, Access and GT were selected from new generation banks while First Bank and UBA were chosen from earlier established banks. The observation runs from 2006 through 2017.

According to [1] Abu, Okpeh, \& Okpe (2016), two categories of variables are required for this research. The first category involves those which measure board diversity such as, board size, non-executive directors, and gender diversity. The second category involves those which measure firm financial performance, from where Returns on Equity (ROE) and Return On Assets (ROA) were chosen. The use of ROE and ROA as the measure for firm's performance has been very popular in literature. It is in line with the work of authors such as [53] Alm and Winberg (2016), [51] Zainali, Zulkifi, \& Saler, (2013), and [1] Abu, Okpeh, \& Okpe (2016). To ensure that all the data are expressed in the same unit for easy interpretation, the natural $\log$ of all the variables was obtained and used. Subsequent sections describe the data construction for all the variables.

\subsection{Data Construction for Board Diversity Variables}

\subsubsection{Board Size}

To obtain this data, information on the total number of members on the board of directors is required. This is usually found on companies' annual report. The data is defined as the total number of directors on the board

\subsubsection{Independent/Non-Executive Directors}

Companies' annual reports usually contain information on the designation of directors. Researchers use the ratio of non-executive directors to the total number of directors on the board, which was also adopted for this present research.

\subsubsection{Gender Diversity (Proportion Women Directors)}

Researchers such as [1] Abu, Okpeh, \& Okpe (2016) use the ratio of total number of female directors to the total number of directors. This was also adopted for this present research

\subsection{Data Construction for Financial Performance Variables}

\subsubsection{Returns on Assets}

This data is constructed from the financial statement section 
of the annual report. It is gotten as the ratio of net income before tax to total assets. This will be calculated for the individual years in the observation

\subsubsection{Returns on Equity}

This data can also be constructed from financial statement. It is gotten as the ratio of net income before tax to shareholder equity. This is calculated for the individual years in the observation.

\subsection{Estimation Technique}

According to literature review in section 2, panel data has been widely used for estimation in this topic thus, the researchers also adopted it for estimation for this present research. This is because the sample involves cross section of five banks as well as time series dimension. The vital aspect of the analysis is the correlation analysis. Through this analysis, the researchers were able to easily determine the nature of the relationship between board diversity variables and firm performance thus, providing some insight into the research hypotheses. Nevertheless, for in-depth analysis and deeper insights to the research questions, the researchers went ahead to run regressions in order to further understand the nature of the relationship and the exact impact of such board diversity variables on financial performance, as recommended in [1] Abu, Okpeh, \& Okpe (2016)

For the purpose of regressions, board diversity is used as explanatory (right-hand side) variables and financial performance is used as the depednent (left-hand side) Variable. The model is described below in section 3.4.1

\subsubsection{Estimate Equation}

$$
\text { Yit }=\beta 0+\beta 1 X \text { it }+\varepsilon t
$$

Where,

it $=$ denotes panel of bank $\mathrm{i}$ at time $\mathrm{t}$

$\mathrm{Y}=$ denotes financial performance variables $\mathrm{ROE}, \mathrm{ROA}$

$\beta 0=$ denotes the constant

$\beta 1=$ denotes the coefficients

$\mathrm{X} 1=$ denotes the explanatory variables board size $(\mathrm{BS})$, independent/non-executive directors (INED), and gender diversity $(\mathrm{G})$

$\varepsilon \mathrm{t}=$ denotes the error term (other variables which may also affect financial performance)

For clarity, equation 1 can be expanded and rewritten as,

$$
\begin{aligned}
& \text { ROA }_{\text {it }}=\beta_{0}+\beta_{1} \mathrm{BS}_{\text {it }}+\beta_{2} \mathrm{INED}_{\text {it }}+\beta_{3} \mathrm{G}_{\text {it }}+\varepsilon \mathrm{t} \\
& \text { ROEit }=\beta_{0}+\beta_{1} \mathrm{BS}_{\mathrm{it}}+\beta_{2} \mathrm{INED}_{\mathrm{it}}+\beta_{3} \mathrm{G}_{\mathrm{it}}+\varepsilon \mathrm{t}
\end{aligned}
$$

The equations 2 and 3 are basically the same. They assess the impact of board diversity using two financial performance indicators, ROA and ROE.

\subsubsection{Explanation of Panel Data Estimation Concepts and Their Implications}

There are two models available for estimating a panel data.
They are the fixed effects model (FEM) and the random effects model (REM). The appropriateness of a model depends on a formal test known as the Hausman Test. This test determines whether error terms are correlated or not with explanatory variables as outlined in [27] Gujarati \& Porter (2010). If correlated then fixed effects model is appropriate but if not correlated then randome effects is appropriate. This approach is widely used in panel data empirical papers.

i. Hausman Test Procedure

H0: the error terms are correlated with explanatory variables thus, fixed effects is appropriate

Ha: error terms are uncorrelated with explanatory variables thus, random effects is appropriate

Decision Rule: If $\mathrm{p}$-value following the chi-square statistic is greater than 0.05 , accept $\mathrm{H} 0$ and reject $\mathrm{Ha}$

\section{Results and Analysis}

In this section, the authors present the results, interpret them in the light of the research questions posed and hypotheses to be tested and further discuss findings in light of the literature review. The section begins with 4.1 where the presentation of the data through graphs, and the discussions of the descriptive statistics are provided. Section 4.2 focuses on correlation analysis and regressions in other to test the hypotheses developed and to provide answers to the research questions posed. Section 4.3 discusses the findings in light of literature review

\subsection{Discussion of Trend and Distribution of Data}

The data for all the variables is presented on figures 1-5 below for the individual banks used for this research.

Figure 1 shows that Nigerian banks have had varying number of board members throughout the observation period. Access bank and UBA seem to have higher variations over the years than the rest of the banks. GT bank has had the highest stability in maintaining same number of board members over the observation period

From figure 2, a first glance shows that GT bank is the only bank to have maintained same number of non-executive board members for longer period of time. Other banks show very high degree of fluctuations

From figure 3, number of women on the board has varied greatly among all the banks, though GT bank also records more stability, see between 2011 and 2015. First bank recorded the lowest women directors between 2006 and 2014. Zenith bank on the other hand seems to be varying the number of women directors every two years

Graph for returns on assets on figure 4 shows a great variation yearly, with a little exception of GT bank, which is the only bank to show positive growth and recorded persistent increase between 2011 and 2013. However, GT bank recorded a great fall after 2013 with no effort to revamp since then. Zenith bank on the other hand, seems to have been struggling after recording reasonable growth in 2006 though presently in a much better situation than GT, first bank and Access. Nonetheless, the 2016 recession seems to have impacted 
greatly on all the banks, evidenced by the slump observed between 2015 and 2016 on the graphs

The graph on figure 5 for returns on equity has generally shown a more stable pattern compared to returns on assets. Unlike return on assets, there has been positive growth for all the banks in question. GT bank and first bank seem to be doing really well compared to others, however, Zenith bank has picked up massively since 2016. It shows that perhaps, Zenith bank is recovering quicker from the recession than other banks.

Table 1. Descriptive Statistics.

\begin{tabular}{llllll}
\hline & ROE & ROA & NON_EXECUTIVE_DIRECTORS & FEMALE_DIRECTOR & BOARD_SIZE \\
\hline Mean & 7.562051 & 2.342223 & 0.173970 & 0.196315 & 12.80952 \\
Median & 7.117046 & 0.017889 & 0.133929 & 0.200893 & 14.00000 \\
Maximum & 18.21648 & 52.62169 & 0.333333 & 0.428571 & 19.00000 \\
Minimum & 1.142230 & -0.009898 & 0.100000 & 0.000000 & 7.000000 \\
Std.Dev. & 3.111068 & 10.54207 & 0.084038 & 0.093313 & 3.710487 \\
Skewness & 0.703159 & 4.294116 & 1.065808 & 0.333608 & -0.384243 \\
Kurtosis & 4.833882 & 19.57941 & 2.497635 & 2.803244 & 1.830781 \\
Jarque-Bera & 9.346491 & 610.1104 & 8.393279 & 0.846806 & 3.425879 \\
Probability & 0.009342 & 0.000000 & 0.015046 & 0.654815 & 0.180335 \\
Sum & 317.6061 & 98.37338 & 7.306746 & 8.245211 & 538.0000 \\
SumSq.Dev. & 396.8284 & 4556.541 & 0.289556 & 0.356996 & 564.4762 \\
Observations & 42 & 42 & 42 & 42 & 42 \\
\hline
\end{tabular}

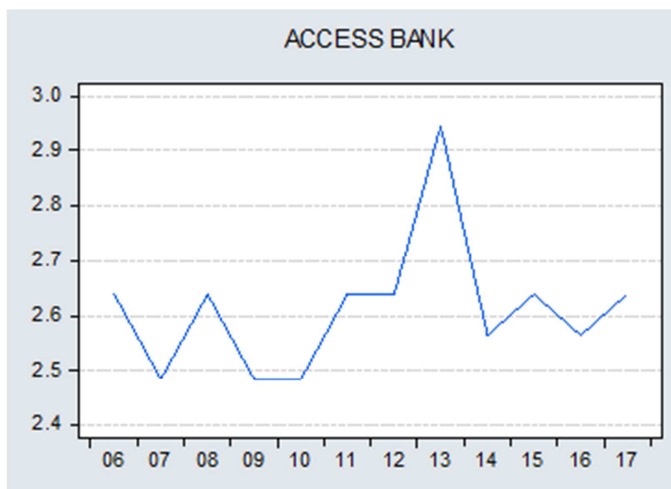

ZENITH BANK

GT BANK

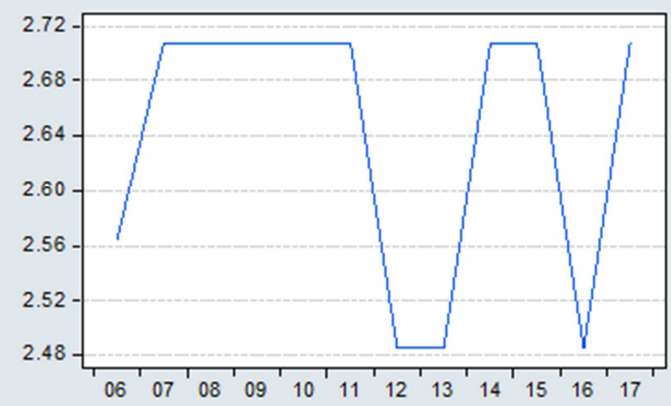

FIRST BANK
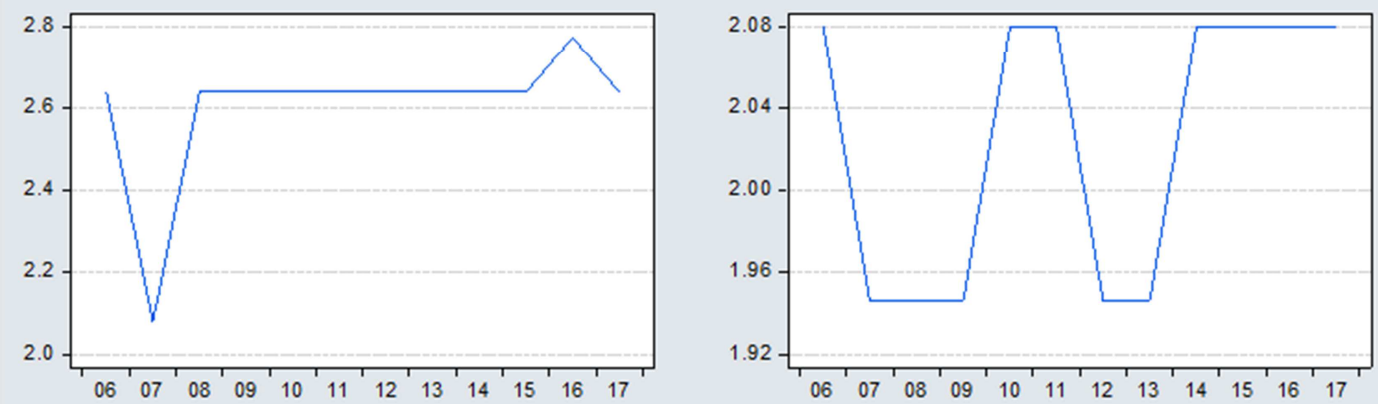

UBA

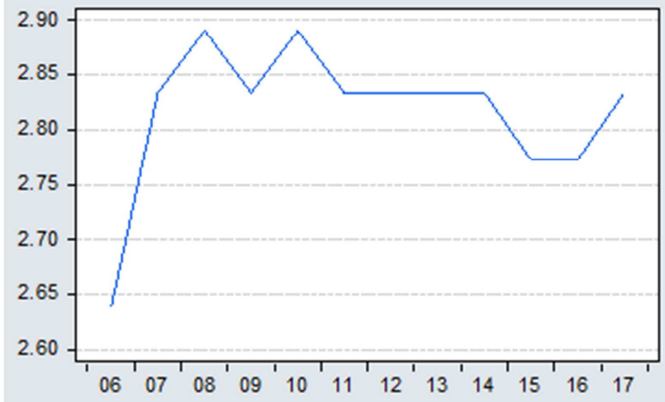

Figure 1. Graph of Board Size. 


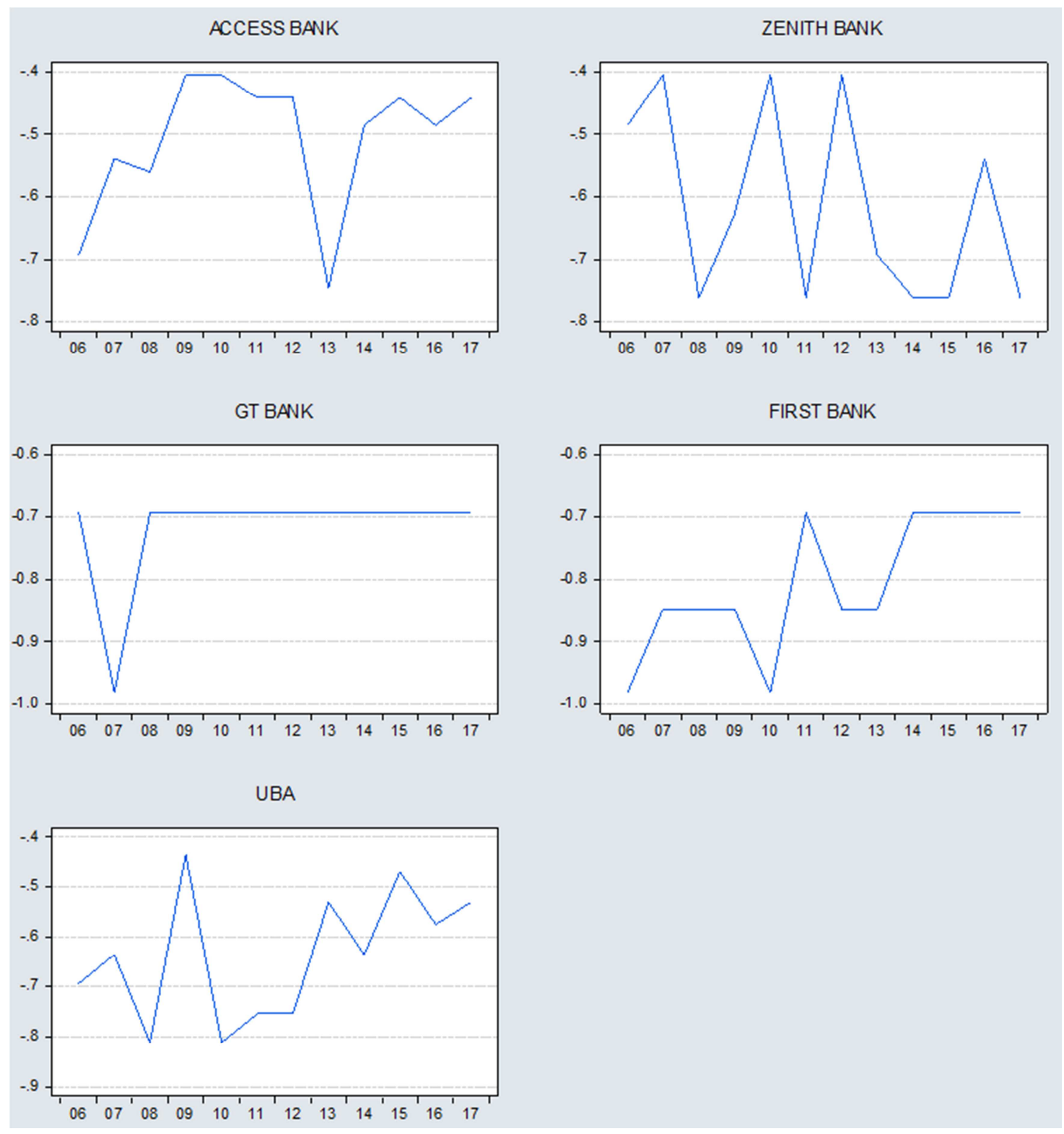

Figure 2. Graph of Non-Executive Directors.

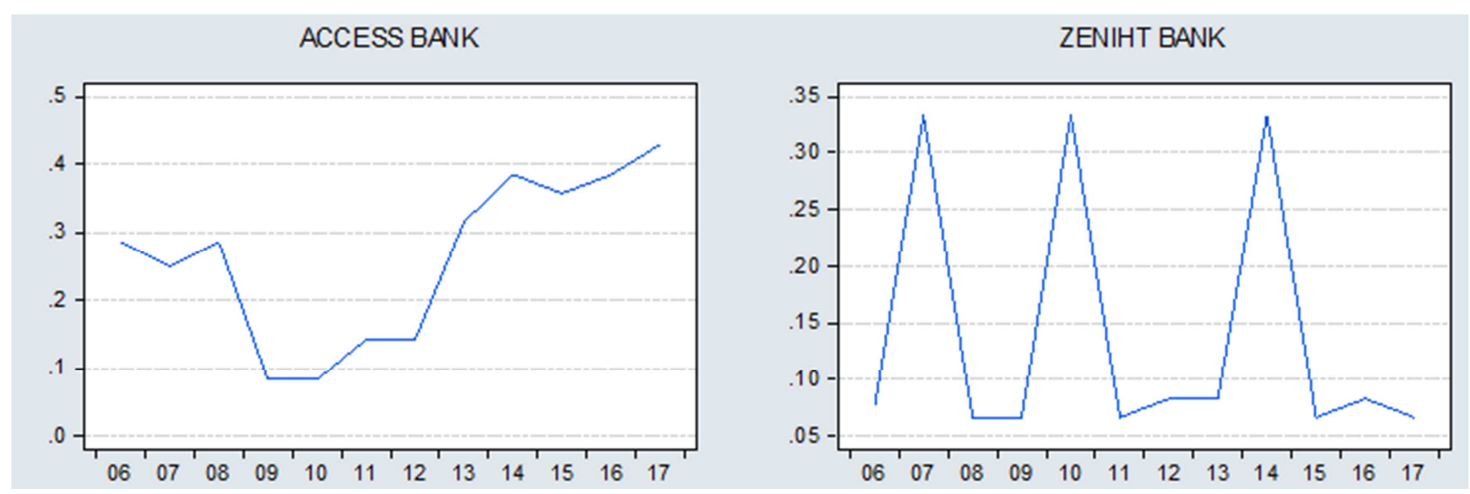


GT BANK

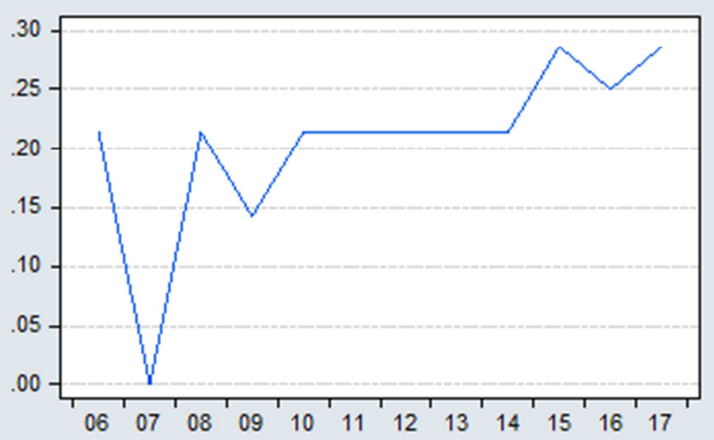

UBA

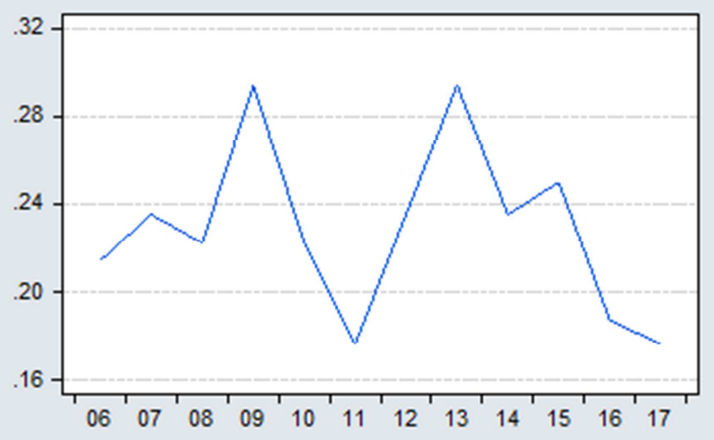

Figure 3. Graph of Female Directors.

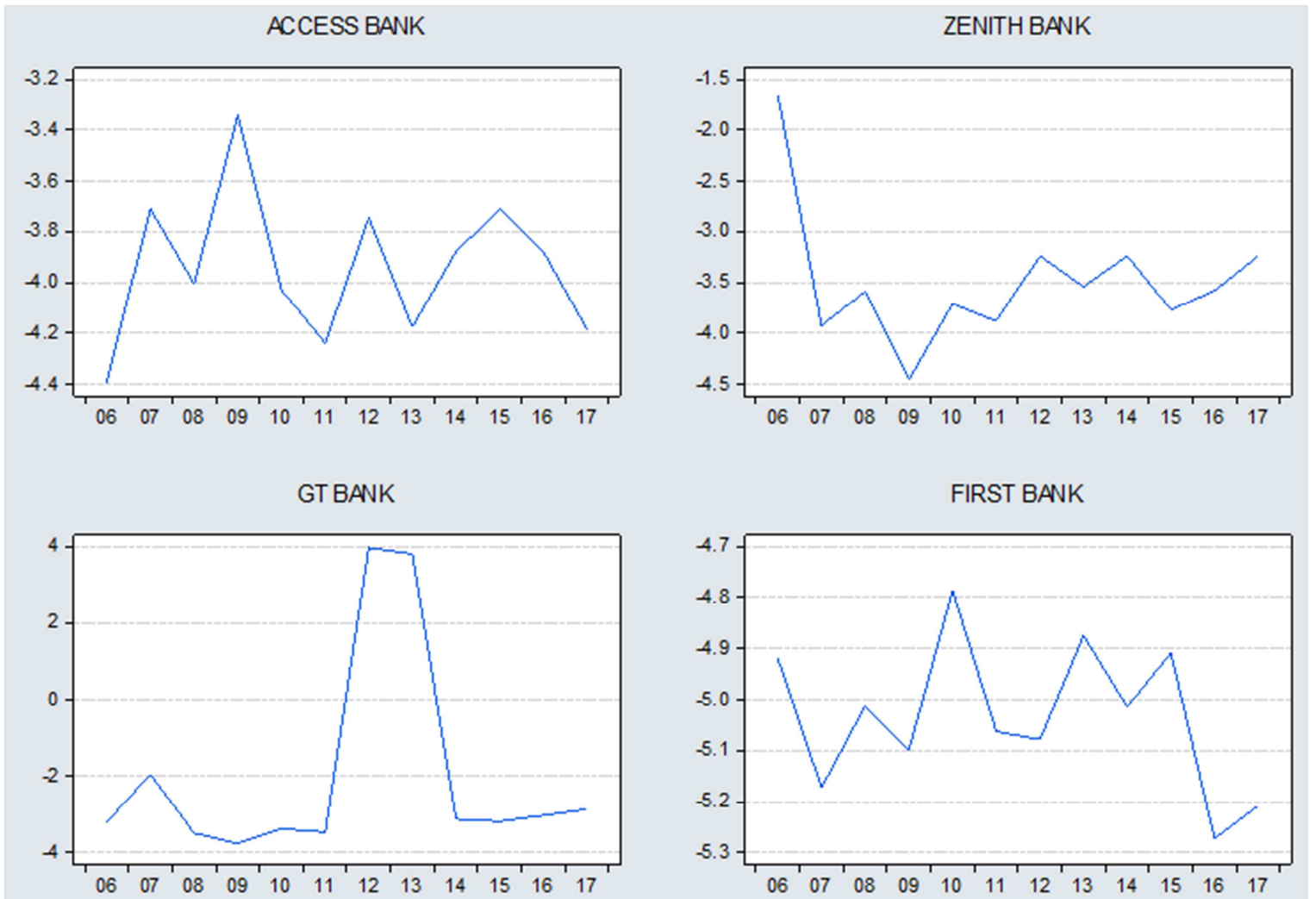




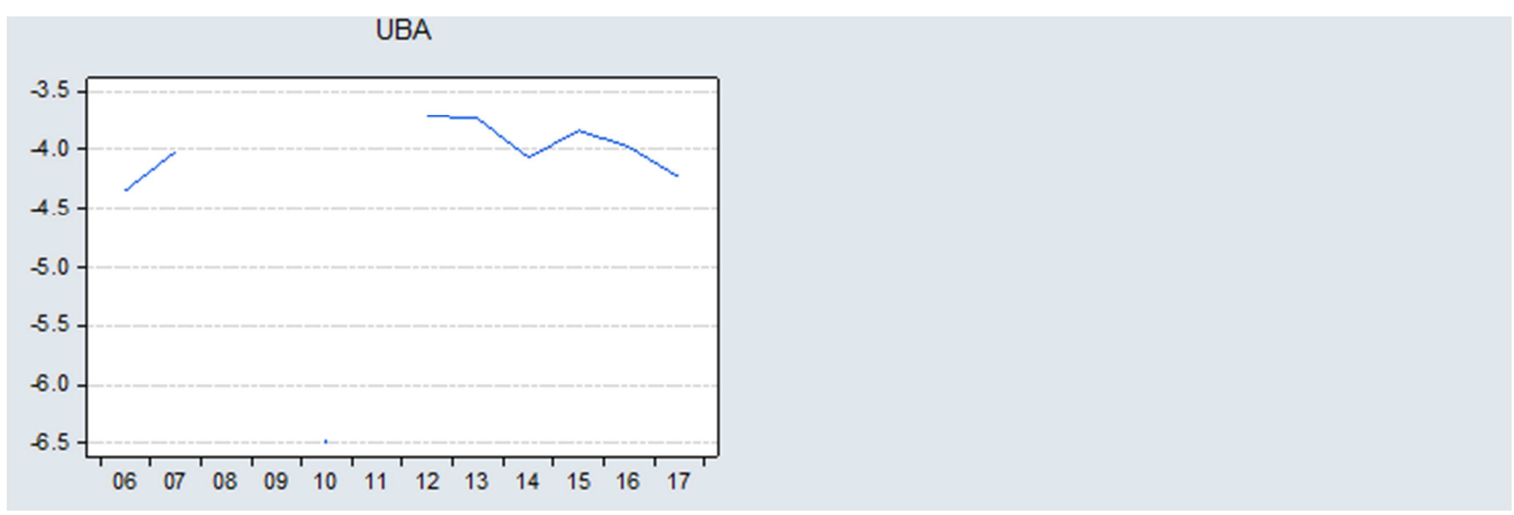

Figure 4. Graph of Return on Assets.

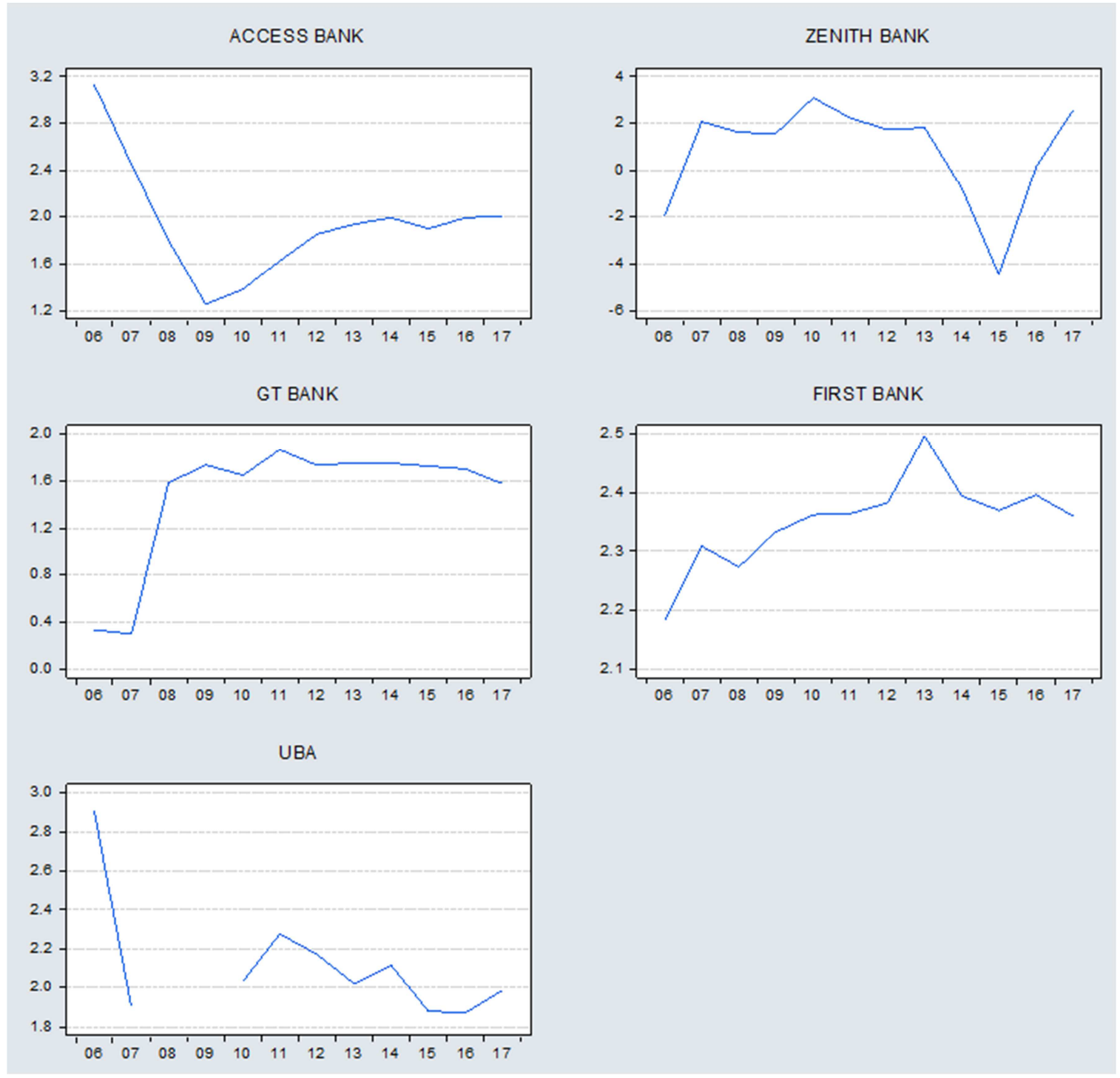

Figure 5. Graph of Return on Equity.

A careful observation of the table above for financial performance variables shows that ROE has a higher mean score than the ROA. This means on average, all the banks in the sample have higher ROE than they have ROA. For board diversity variable, board size produced a mean score of 12 . This means that on average, all the banks in the sample have about 12 members on the board. Female directors with a mean score of 0.19 shows that, in comparison to total board members, women directors make up only about $19 \%$ of total board. Finally, non-executive directors with produced a mean score of 0.17 which means that on average, non-executive directors make up only about $17 \%$ of the total board members. 
A further look at the Jarque-Bera probability value shows that ROE, ROA and Non-Executive director variables do not follow normal distribution, evidenced by significant $p$-values at $5 \%$. The reverse is true for female director and board size. Nonetheless, the central limit theorem according to Gujarati \& Porter (2010) permits the use of variables for analysis even though they do not follow normal distribution, with the argument that normal distribution depends on the type of sample the researcher obtains. Thus, we proceed with analysis using all the variables

\subsection{Correlation Analysis}

The purpose of conducting this correlation analysis is to determine the nature of the relationship between board diversity variables and financial performance for the chosen banks. Table 2 below shows the EViews output for the correlation.

Table 2. Correlations Analysis.

\begin{tabular}{|c|c|c|c|c|c|}
\hline Correlation & RETURN_ON_EQUITY & RETURN_ON_ASSET & $\begin{array}{l}\text { NON_EXECUTIVE_ } \\
\text { DIRECTORS }\end{array}$ & $\begin{array}{l}\text { FEMALE } \\
\text { DIRECTOR }\end{array}$ & BOARD_SIZE \\
\hline \multirow[t]{2}{*}{ RETURN_ON_EQUITY } & 9.448296 & & & & \\
\hline & 1.000000 & & & & \\
\hline \multirow[t]{2}{*}{ RETURN_ON_ASSET } & -4.336887 & 108.4891 & & & \\
\hline & -0.135459 & 1.000000 & & & \\
\hline \multirow[t]{2}{*}{$\begin{array}{l}\text { NON_EXECUTIVE_DIR } \\
\text { ECTORS }\end{array}$} & 0.105574 & -0.072211 & 0.006894 & & \\
\hline & 0.413655 & -0.083497 & 1.000000 & & \\
\hline \multirow[t]{2}{*}{ FEMALE_DIRECTOR } & 0.054909 & 0.041279 & -0.003085 & 0.008500 & \\
\hline & 0.193757 & 0.042986 & -0.402980 & 1.000000 & \\
\hline \multirow[t]{2}{*}{ BOARD_SIZE } & -3.819657 & 2.765156 & -0.276188 & 0.128161 & 13.43991 \\
\hline & -0.338961 & 0.072415 & -0.907331 & 0.379185 & 1.000000 \\
\hline
\end{tabular}

The correlation results on table 2 above gives a direction of what to expect from the regression results. For each variable, the first value represents the covariance score used in the calculation of the second value which give the correlation score. Interest is only with the correlation between board diversity variables and financial performance which are highlighted in bold red for easy identification. Using ROE as a financial performance measure, it can be discovered that having non-executive directors on board has a positive relationship with financial performance but using ROA it becomes negative. This kind of situation repeated in board size, where negative correlation is found for ROE but positive for ROA. Moreover, gender diversity represented by proportion of women directors on the board has remained positive both for ROA and ROE. This is a strong evidence of positive relationship between women directors and financial performance of banks. From the discrepancy in result in the correlation of board size and non-executive directors to ROA and ROE, one can say that perhaps, board diversity can have either positive or negative impact on performance, depending on the proxy used in measuring performance.

Nevertheless, this correlation result alone may not be sufficient to provide strong evidence on the nature of the relationship between board diversity variables and financial performance, Thus, the researcher employs a regression analysis in order to conduct further investigation into the nature of this relationship by assessing the probability values.

\subsection{Regression Estimates}

Table 3. Hausman Test for ROE.

\begin{tabular}{llll}
\hline Correlated Random Effects-Hausman Test & Chi-Sq. Statistic & Chi-Sq. d.f. & Prob. \\
\hline Test Summary & 1.565860 & 3 & 0.6672 \\
\hline
\end{tabular}

Table 4. Hausman Test for ROA.

\begin{tabular}{llll}
\hline Correlated Random Effects-Hausman Test & Chi-Sq. Statistic & Chi-Sq. d.f. & Prob. \\
\hline Test Summary & 0.267960 & 3 & 0.9659 \\
\hline
\end{tabular}

Tables 3 and 4 above gives the result from the Hausman test. As stated in methodology, the p-values are greater than 0.05 which led to the failure to reject the null hypothesis which states that the error terms are correlated with explanatory variables. Thus, we proceed with the use of the results from the fixed effects model.

Table 5. Fixed Effects Results for ROE.

\begin{tabular}{lllll}
\hline Variable & Coefficient & Std. Error & t-Statistic & P value $^{\mathbf{2}}$ \\
\hline Non-Executive Director & 0.213073 & 11.94923 & 0.017832 & 0.2200 \\
Board Size & -0.064735 & 0.286535 & -0.225925 & 0.8226 \\
Female Director & 9.826364 & 4.508818 & 2.179366 & 0.0363 \\
\hline
\end{tabular}


Table 6. Fixed Effects Results for ROA.

\begin{tabular}{llllll}
\hline Variable & Coefficient & Std. Error & t-Statistic & P value & $\mathbf{R}^{2}$ \\
\hline Non-Executive Director & -47.46952 & 57.19643 & -0.829939 & 0.4124 & 0.272360 \\
Board Size & -0.363574 & 21.58200 & -0.016846 & 0.9867 & \\
Female Director & 0.163507 & 1.371534 & -0.119215 & 0.9058 & \\
\hline
\end{tabular}

Tables 5 and 6 above give the fixed effects regression estimate for Return on Equity and return on Asset respectively. Using ROE as performance measure, a first glance at probability values shows that the estimates for female director is statistically significant at 5\%. While other variables, Board Size and Female Director remain statistically insignificant. This estimate produced an R-squared value of 0.64 which means that the model explains $64 \%$ of the variations in $\mathrm{ROE}$ for the Nigerian Banks in the sample.

The Coefficient of 9.83 for women directors implies that an increase in the number of women on the board by $1 \%$ will increase financial performance by about $10 \%$, which leads to the rejection of the null hypotheses in this research which state that women directors have no relationship with financial performance of Nigerian Banks.

Coefficients for the remaining variables (Board size and non-executive directors) on the other hand, are not statistically significant; therefore, one may not say with confidence that board size and non-executive director has any impact on financial performance. Thus, a failure to reject these hypotheses which states that board size and non-executive directors have no relationship with financial performance of Nigerian banks.

Using ROA as measure of performance as shown on table 6 above, we observe statistically insignificant results for all variables, implying that all board diversity variables do not have any impact on ROA. However, the model produced $\mathrm{R}^{2}$ of 0.27 which indicates that the model has explained about $27 \%$ of variations in ROA.

As can be observed from the two equations (using ROA and $\mathrm{ROE}$ ), the results contradict each other on female director, but both models agree that board size and non-executive directors have no impact on financial performance. Using ROE shows that there is a significant positive impact for female directors, while using ROA says there is no impact. Nevertheless, taking a realistic approach, one can admit that even when ROA and ROE may be used to proxy for financial performance, these two variables (ROA, ROE) by definition actually measure slightly different things as was shown on data construction section. Thus, it is not totally illogical that two different results should emerge. It therefore does not mean that one result is wrong and one is right, it just means that board diversity variables impact different on different performance indicators. Thus, one can conclude that having more women directors increases ROE but may not have any impact on ROA.

\subsection{Discussion of Findings}

The finding of this present paper is consistent with the findings of authors such [52] Anderson, Reeb, Upadhyay, and Zhao (2011) [42] Oxelheim and Randøy (2003), [48] Terjesen,
Couto, \& Francisco (2015), [32] Krishnan and Park (2005), [11] Carter, Simkins and Simpson (2003), and [4] Ali \& Nasir (2015). These authors argue strongly that having more women on the board, have significant positive impact on Financial Performance. Although not all these papers are done for financial sector but the choice of similar variables make the result of the papers highly comparable to the results from this present research.

Nevertheless, the results from this present research to a great extent, contradicts the findings of other authors who either argue for negative impact such as [52] Anderson, Reeb, Upadhyay, and Zhao (2011), and [3] Adams and Ferreira (2009) or no impact such as [53] Alm and Winberg (2016), [51] Zainali, Zulkifi, \& Saler (2013), [44] Rose (2007), and [1] Abu, Okpeh, \& Okpe (2016). Nonetheless, papers done for other countries and industries may not be expected to arrive at same result due to different business and cultural environments. But expectations may be that the results from the work of [1] Abu, Okpeh, \& Okpe (2016) should be consistent with that of this paper as both studies are conducted for the same country (Nigeria) and industry (Banking sector), with same variables. To some extent it does agree, as board size and non-executive director were generally found to have no impact. Yet, [1] Abu, Okpeh, \& Okpe (2016) argues strongly that Women directors has no impact on financial performance, which is contradictory to this present research.

However, there are possible explanations why the results of this study differ greatly to that of [1] Abu, Okpeh, \& Okpe (2016). Firstly, the observation period of [1] Abu, Okpeh, \& Okpe (2016) ended in 2014 while that of this study extends to 2017. This makes a huge difference because, between 2014 and 2017, a lot has happened in Nigeria starting from the change in political power from Goodluck Jonathan administration to Muhammadu Buhari in 2015, to the economic recession in 2016 which may have resulted to the change in results from those of [1] Abu, Okpeh, \& Okpe (2016). Furthermore, this present research adopts a more sophisticated model (panel data) while [1] Abu, Okpeh, \& Okpe (2016) seem to have adopted time series analysis by aggregating the data from all the banks in their sample. Thus, different results become inevitable. These differences both in approach to data analysis and economic impacts arising from different time periods may have resulted to these differences between this present research and [1] Abu, Okpeh, \& Okpe (2016).

\section{Conclusions}

This section provides a summary of this research. It is sub-divided in to three sections. Section 5.1 discusses findings in the light of research questions to show how they have been 
addressed; section 5.2 discusses the implication of the findings and provides recommendations. Finally, section 5.3 discusses the limitations of the research and recommends areas for further improvement and study to future researchers.

\subsection{Summary of Findings/Addressing Research Objectives}

The purpose of this research was to investigate and reveal the nature of the relationship between board diversity and corporate financial performance. In the light of this, five Nigerian banks quoted on the Nigerian stock exchange were chosen for the research, with observation running from 2006-2017. The board diversity variables of interest include, women directors, non-executive directors and board size. While the financial performance variables of interest include Return on Assets (ROA) and Return on Equity (ROE). The research methodology adopted both correlation analysis, and multi-liner regressions of the panel data using Fixed Effects model. The results are discussed under the heading below for each of the three research questions.

\subsubsection{Board Size and Commercial Banks Financial Performance (RQ1)}

The regression analysis for this research question produced insignificant results for both ROA and ROE which led to the failure to reject the null hypothesis which states that board size has no significant relationship with financial performance of Nigerian banks. This means that board size does not have any impact on corporate financial performance of Nigerian banks.

\subsubsection{Non-executive Directors and Commercial Banks Financial Performance (RQ2)}

The regression results for research question 2 also produced an insignificant relationship at 5\%, which led to the failure to rejection the null hypothesis which states that non-executive director has no significant relationship with financial performance. Thus, the inference was drawn that having non-executive directors on the board has no effect on financial performance of Nigerian banks.

\subsubsection{Women directors and Commercial Banks Financial Performance (RQ3)}

The regression results for this research question, unlike RQ1 and RQ2, produced a significant positive relationship at $5 \%$. This led to the rejection of the null hypothesis which states that women director has no significant relationship with financial performance. Thus, the inference was drawn that having more women directors on the board improves financial performance of Nigerian commercial banks. This impact was calculated to be about $10 \%$.

\subsection{Recommendations}

Agency theory of corporate governance emphasize the need to have diversity on the board of directors. The results of this research are in line with this agency theory. It is therefore highly recommended and rewarding for Nigerian banks or other institutions to incorporate more women on the board, so as to improve financial performance. As noted earlier in [36] Nielsen \& Huse, (2010), and [6] Azmi \& Barrett, (2013) which explain the importance of women on the board state that female directors reduce the level of conflict in corporate boards, and effectively use board development activities, such as work instructions, evaluations, and development programs to improve board efficiency and effectiveness [6] (Azmi \& Barrett, 2013). In addition, women are meticulous, risk averse, skilled in accounting and finance, and good decision-makers. Thus, organisations should involve more women in strategic positions to boost their level of performance. To put it in a nutshell, organisations should note that having more non-executive directors or having larger number of directors on the board is not as important as having more women on the board.

\subsection{Limitations of the Research}

The Major limitation of this research is the small observation period covered. Therefore, it is recommended that researchers interested in this topic area should try to gather as much data as possible in order to get more robust findings. Secondly, the process of obtaining data was very tedious. That is, extracting data individually for the five banks from yearly annual reports for the period of ten years covered which means that there is a possibility that some data may have been captured incorrectly. Furthermore, there is even no guarantee that the banks reported the real information on their annual reports as the cases of window dressing is eminent with large corporations. These limitations imply that companies or policy makers wishing to use the result of this paper for policy making or other improvement strategies should do so with some level of caution.

\section{Acknowledgements}

There are two people whom we deem fit to be acknowledged. First is $\mathrm{Mr}$ Thomas Ayim, who is an accounting lecturer at Aduvie Pre University, Abuja Nigeria. He provided helpful advice during the construction of the variables used in the research. Another individual who contributed immensely is Miss Ibukun Ogbo, who is a teacher at Broad Oaks British School, Abuja Nigeria. Miss Ibukun helped in the proofreading and editing of the paper.

\section{References}

[1] Abu, S. O., Okpeh, A. J., \& Okpe, U. J. (2016). Board Characteristics and Financial Performance of Deposit Money Banks in Nigeria. International Journal of Business and Social Science, 7 (9).

[2] Abubakar, A. (2018). Corporate Board Diversity and Financial Performance: Panel Data Evidence from Quoted Deposit Money Banks in Nigeria. AL-Muqaddimah Journal of Humanities, Law Social and Management Sciences (1), 1.

[3] Adams, R. B., \& Ferreira, D. (2009). Women in the boardroom and their impact on governance and performance. Journal of Financial Economics. Journal of Financial Economics, 94 (2), 291-209. 
[4] Ali, A., \& Nasir, S. B. (2015). IMPACT OF BOARD CHARACTERISTICS AND AUDIT COMMITTEE ON FINANCIAL PERFORMANCE: A STUDY OF MANUFACTURING SECTOR OF PAKISTAN. Business Review, 10 (1).

[5] Anis, M., Chizema, A., Lui, X., \& Fakhreldin, H. (2017). The Impact of Board Charracteristics on Firms Financial Performance-Evidence from the Egiptians listed companies. Global Journal of Human-Social Science, 17 (5), 1.

[6] Azmi, I. A., \& Barrett, M. (2013). Women on Boards and Company Financial Performance: A study of Malaysian Smes.

[7] Bernardi, R., \& Threadgill, V. (2010). Women Directors and Corporate Social Responsibility. Electronic Journal of Business Ethics and Corporate Social Responsibility.

[8] Boone, A. L., Field, L. C., Karpoff, J. M., \& Raheja, C. G. (2006). The determinants of corporate board size and composition: An empirical analysis. Retrieved January 4, 2019, from http://www.ssrn.com/abstract=605762

[9] Burgess, Z., \& Tharenou, P. (2002). Women board directors: Characteristics of the few. Journal of Business Ethics, 37, $39-49$.

[10] Campbell, K., \& Mingues-Vera, A. (2008). Gender diversity in the boardroom and firm financial performance. Journal of Business Ethics, 83, 435-451.

[11] Carter, D. A., D'Souza, F., Simkins, B. J., \& Simpson, W. G. (2010). The Gender and Ethnic Diversity of US Boards and Board Committees and Firm Financial Performance. Corporate Governance: An International Review, 18 (5), 396-414. doi: $10.1111 / \mathrm{j} .1467-8683$

[12] Carter, D., Simkins, B., \& Simpson, W. (2003). orporate governance, board diversity, and firm value. Financial Review, $38(1), 33-53$

[13] Central Bank of Nigeria. (2011). List of financial institutions. Abuja: Central Bank of Nigeria (CBN). Retrieved December 4, 2018, from http://www.cenbank.org/Supervision/Inst-DM.asp

[14] Connell, V., \& Cramer, N. (2010). The Relationship Corporate Performance and Board Charracteristics in Ireland. European Management Journal, 28, 387-39.

[15] De Andres, P., Azofra, V., \& Lopez, F. (2005). Corporate boards in OECD countries: Size, composition, functioning and effectiveness. Corporate Governance, 13 (2), 197-210.

[16] Dehaene, A., De Vuyst, V., \& Ooghe, H. (2001). Corporate Performance and Board Structure in Belgian Companies. Long Range Planning, 34 (3), 383-398.

[17] Dobbin, F., \& Jung, J. (2011). Corporate board gender diversity and stock performance: The competence gap or institutional investor bias. North Carolina Law Review, 89 (3), 809-838.

[18] Dorger, M. (2011). Size matters: Right sizing your board of directors. Retrieved December 28, 2018, from http://dorgerconsulting.com/2011/07/20/sizematters-right-sizin g-your-Board-of-directors/\#respond

[19] Easterwood, J. C., Ince, O. S., \& Raheja, C. G. (2012). The evolution of boards and CEOs following performance declines. Journal of Corporate Finance, 18, 727-744.

[20] European Commission. (2014). Gender balance on corporate boards: Europe is cracking the glass ceiling. Istanbul: European Commission. (2014). Gender balance on corporate boards: Europe is cracking the glass ceiling. [Online] Available: $\mathrm{http}: / /$ ec.europa.eu/justice/gender-equality/index_en.htm. (March 7, 2014). Retrieved December 4, 2018, from http://www.ec.europa.eu/justice/gender-equality/index_en.htm.

[21] Fama, E., \& Jensen, M. (1983). The Separation of Ownership and Control. Journal of Law and Economics, 26, 301-325.

[22] Farrell, K. A., \& Hersch, P. L. (2005). Additions to corporate boards: The effect of gender. Journal of Corporate Finance, 11, 85-106.

[23] Ferreira, D. (2010). Board diversity. Retrieved January 3, 2019, from

http://wwwpersonal.lse.ac.uk/FERREIRD/Board\%20Diversity $\% 20$ version\%201.pdf

[24] Fidanoski, F., Mateska, V., \& Simeonovski, K. (2014). Corporate Governance and Bank Performance: Evidence from Macedonia. Economic Analysis, 47 (1-2), 76-99.

[25] Garba, T., \& Abubakar, B. (2014). Corporate Board Diversity and Financial Performance of Insurance companies in Nigeria: An Application of Panel Data Approach. Asian Economic and Financial Review, 4 (2), 257-277.

[26] Grosvold, J., Rayton, B., \& Brammer, S. (2015). Women on Corporate Boards: A Comparative Institutional Analysis. Business \& Society. doi: 10.1177/0007650315613980.

[27] Gujarati, D. N., \& Porter, D. C. (2010). Essentials of Econometrics. New York: McGrall-Hill/Irwin.

[28] Hillman, A. J., Cannella, A. A., \& Harris, I. C. (2002). Women and racial minorities in the boardroom: how do directors differ? Journal of Management, 28 (6), 747-763.

[29] Jensen, M. C. (1993). The modern industrial revolution, exit and the failure of internal control system. Journal of Finance, $48(3), 831-880$.

[30] Jensen, M. C., \& Meckling, W. (1976). Theory of the firm: Managerial behavior, agency costs and ownership structure. Journal of Financial Economics, 3 (4), 305-360.

[31] Kiel, G. C., \& Nicholoson, G. J. (2003). Board composition and corporate performance: How the Australian experience informs contrasting theories of corporate governance. Corporate Governance: An International Review, 11, 189-205.

[32] Krishnan, H. A., \& Park, D. (2005). A few good women: On top management teams. Journal of Business Research, 58, $1712-1720$.

[33] Laible, M. C. (2013). Gender diversity in top management and firm performance: An analysis with the IAB-Establishment panel. CAED Conference Paper. Atlanta: Institute for Employment Research.

[34] Naseem, M. A., Xiaoming, S., Riaz, S., \& Rehman, R. U. (2017). BOARD ATTRIBUTES AND FINANCIAL PERFORMANCE: THE EVIDENCE FROM AN EMERGING ECONOMY. The Journal of Developing Areas, $21(3)$.

[35] Nicholson, G. J., \& Kiel, G. C. (2007). Can directors impact performance? A case-based test of three theories of corporate governance. Corporate Governance, 15 (4), 585-608. doi: $10.1111 / j .1467-8683.2007 .00590 . X$. 
[36] Nielsen, S., \& Huse, M. (2010). The contribution of women on boards of directors: Going beyond the surface. Corporate Governance: An International Review, 18, 136-148.

[37] Ning, Y., Davidson, W. N., \& Wang, J. (2010). Does Optimal Corporate Board Size Exist? An Empirical Analysis. Journal of Applied Finance (Formerly Financial Practice and Education), $20(2), 14$

[38] O'Connell, V., \& Cramer, N. (2010). The relationship between firm performance and board charracteristics in Ireland. European Management Journal, 28, 387-399.

[39] Ogbechie, C., \& Koufopoulos, D. N. (2010). Corporate Governance and Board Practices in Nigerian Banking Industry.

[40] Okon, E., \& Afza, N. (2014). Board Charracteristics and company performancer: Evidence from Nigeria. Journal of Finance and Accounting, 2 (3), 81-89.

[41] Oludele, O., Margret, O., \& Tobiah, O. (2016). The Relationship between Board Independence and Financial performance of of listed manufacturing companies in Nigeria. European Journal of Business, Economics and Accountancy.

[42] Onakoya, A., Ofeegbu, D. I., \& Fasanya, I. (2009). Corporate Governance and Bank Performance: A Pooled Study of Selected Banks in Nigeria. European Scientific Journal, 8 (28).

[43] Oxelheim, L., \& Randoy, T. (2003). The impact of foreign board membership on firm value. The Research Institute of Industrial Economics, Working paper No. 567.

[44] Phan, P., \& Yoshikawa, T. (2000). Agency Theory and Japanese Corporate Governance. Asia Pacific Journal of Management, 17 (1), 1-27. doi: 10.1023/A:1015440702758.

[45] Rose, C. (2007). Does female board representation influence firm performance? The Danish evidence. Corporate Governance, 15 (2), 404-413.
[46] Rosenstein, S., \& Wyatt, J. G. (1997). Inside directors, board effectiveness, and shareholder wealth. Journal of Financial Economics, 44 (2), 229-250.

[47] Security and Exchange Commission of Nigeria. (2011). Code of governance for public companies in Nigeria. Abuja: SEC-N.

[48] Sweigart, A. (2012). Women on board for change: The Norway model of boardroom quotas as a tool for progress in the United States and Canada. North-Western Journal of International Law \& Business, 32 (4), 81A-105A.

[49] Terjesen, S., Couto, E. B., \& Francisco, P. M. (2015). Does the presence of independent and female directors impact firm performance? A multi-country study of board diversity. Journal of Management and Governance.

[50] Tirole, J. (2006). The theory of corporate finance. Princeton, NY: Princeton University Press.

[51] Ujinwa, A., Okoyeuzu, C., \& Nwokoby, I. (2012). Corporate board diversity and firm performance: Evidence from Nigeria. Review of International Comparative Management, 13 (4), 605-620.

[52] Zainali, N., Zulkifi, N., \& Saler, Z. (2013). Corporate diversity in Malaysia: Analysis of a longitutidal characteristics Gender and Nationality Diversity. International Journal of Academic Research in Accounting, Finance and Management Science, 3 (1), 136.

[53] Anderson, R. C., Reeb, D. M., Upadhyay, A., \& Zhao, W. (2011). The Economics of Director Heterogeneity. Financial Management, 40 (1), 5-38.

[54] Alm, M., \& Winberg, J. (2016). How Does Gender Diversity on Corporate Boards Affect the Firm Financial Performance? Gothenburg: University of Gothenburg. 